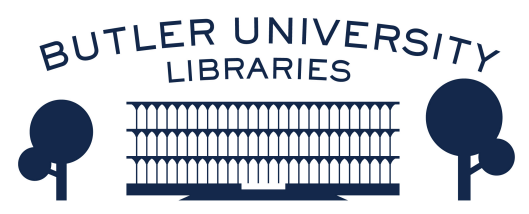

Journal of Hindu-Christian Studies

\title{
Book Review: "Rediscovering God with Transcendental Argument: A Contemporary Interpretation of Monistic Kashmiri Saiva Philosophy"
}

Daniel P. Sheridan

Follow this and additional works at: https://digitalcommons.butler.edu/jhcs

Part of the Religion Commons

\section{Recommended Citation}

Sheridan, Daniel P. (2002) "Book Review: "Rediscovering God with Transcendental Argument: A Contemporary Interpretation of Monistic Kashmiri Saiva Philosophy"," Journal of Hindu-Christian Studies: Vol. 15, Article 18.

Available at: https://doi.org/10.7825/2164-6279.1285

The Journal of Hindu-Christian Studies is a publication of the Society for Hindu-Christian Studies. The digital version is made available by Digital Commons @ Butler University. For questions about the Journal or the Society, please contact cbauman@butler.edu. For more information about Digital Commons @ Butler University, please contact digitalscholarship@butler.edu. 
unfamiliar cultures and religions in order to learn about them firsthand, initiating thereby as well a dialogue with their culture of origin.

The first volume contains eighteen essays, primarily by French Catholics, most of them of a scholarly nature, that cover the range of Monchanin's life from his formation in Lyon through his years on India. Grouped in thematic sections, the essays describe the details of his professional activities in France, the key themes of his theology, and the India he encountered in the 1940s and 1950s. Included as well are comparative and appreciative essays that highlight his impact on other, perhaps better known figures (de Lubac, Le Saux, Griffiths), and laud his contribution to French and Indian theology as an incisive thinker but also as a Christlike human being.

The second volume, as described by Thomas Matus in his preface, balances scholarly essays like those in the first volume with a richer selection of personal remembrances and with something of the spirit of prayerful sharing at the second colloquium held at the ashram Monchanin co-founded. The scholarly essays, written primarily by Indian Christians, discuss Christian ashram life and monasticism in India and offer critical assessments of Monchanin's interreligious experience and theology, followed by some discussion and response among the participants. One is again left with a portrait of this pioneer in dialogue that is at once poignant and thought-provoking. Michael Amaladoss, SJ, affirming Monchanin's sense that only Indians will be able to integrate Christianity and Hinduism, concludes, "The great love and respect that Monchanin had for Indian religious tradition is certainly an inspiration to us Indians. His sacrifical efforts to realize that vision is a continuing challenge to us and to people everywhere to discern and follow our own way of realizing that communion, of which the Trinity continues to remain the inspiration and the force" (Vol. II, 118, 126).

Both volumes are available in the U.S. from Osage Monastery, $18701 \mathrm{~W}$. Monastery Road, Sand Springs, OK 74063.

Judson B. Trapnell

Former Assistant Professor

College of St. Benedict and

St. John's University

\section{Rediscovering God with Transcendental Argument: A Contemporary Interpretation of Monistic Kashmiri Saiva Philosophy. David Peter Lawrence. Albany: State University of New York Press, 1999, 306 pp.}

\begin{abstract}
LAWRENCE'S WORK is a valuable contribution toward the comparative philosophical/theological side of the work of the Society for Hindu-Christian Studies. It should broaden a knowledge and understanding of a most important school of tenth-century Hindu thinkers, the Pratyabhijna [recognition] system of the Kashmiri Saiva thinkers Utpaladeva and Abhinavagupta. Beyond this, however, as a
\end{abstract}

work of scholarship, Rediscovering God is state of the art for four reasons.

First, it is a superb contemporary exposition of the neglected Saiva theistic metaphysics of Utpaladeva (c. 900-950) and Abhinavagupta (c. 975-1025). Jose Pereira has called the Kashmiri Saiva thought of Abhinavagupta "the greatest and most consistent of the Difference-in-Identity theologies." An informed understanding of this tradition will help to correct an over- 
emphasis on Advaita Vedanta's mayavadin non-dualism as the representative Hindu theological system. As Abhinavagupta states in his dedicatory verse, "We praise Siva, who manifests the differentiated universe as the prima facie argument, and then leads it back to unity as the established conclusion."

Second, it is a sophisticated and erudite exercise in cross-cultural methodology in opposition to skeptical relativism and in support of the achievement of a universal intelligibility of differing philosophies. If these philosophies are intelligible, a reflective choice may be made among as to which is more coherent, and thus a greater achievement of truth. Relying on, and advancing beyond, the work of Bernard Lonergan and David Tracey, Lawrence concludes that the "relativization of relativism' . . suggests that universally valid knowledge and values are approachable asymptotically."

Third, Lawrence convincingly concurs with Utpaladeva's and Abhinavagupta's transcendental/ontological argumentation for God's existence. He presents an extensive and sympathetic comparison of this argument with the Thomistic argument of the Jesuit Bemard Lonergan [1904-84] who states, "The existence of God, then, is known as the conclusion to an argument and, while such arguments are many, all of them, I believe, are included in the following general form. If the real is completely intelligible, God exists. But the real is completely intelligible. Therefore, God exists." Lawrence sees a similarity of argumentation in Abhinavagupta, "There are all worldly behaviors by means of this triad of Saktis. By the triad of Saktis of the Blessed One there is the manifestation of [limited individuals such as] Caitra, Maitra, etc., who are the perceivers, rememberers, and [semantically exclusive] conceptualizers [vikalpayitr]. For it is [actually] $\mathrm{He}$ who cognizes, remembers and conceptualizes in this and that form. As it has been said by the precepter: "Although the establishment of objects is concealed by the individual soul as delimited by the vital breaths and psychophysical complex [puryastaka] --neverthelessthat [establishment] is [actually] accomplished in the Supreme Self' . . . If this is not accepted, nothing can appear. Thus is the undesirable consequence. However, [this world] does appear. Therefore, this [the Saiva understanding of the Lord with His Saktis] must necessarily be accepted. Thus there is the avoidance of the undesirable consequence."

Fourth, it is a welcome example of the hermeneutics of charity in action. This hermeneutics takes the thought of a major thinker and treats it with utmost seriousness, avoiding the reductionism of the many varieties of the hermeneutics of suspicion that are so prevalent today. These hermeneutics of suspicion are tempted not to take seriously the carefully-reasoned thought of the other. Lawrence's splendid work will help move the work of the Society of HinduChristian Studies to a new level.

Daniel P. Sheridan Saint Joseph's College of Maine

\section{Hindu God, Christian God. How Reason Helps Break Down the Boundaries between Religions. Francis X. Clooney. Oxford University Press, 2001, viii +209 pp.}

FRANCIS CLOONEY'S latest work (see previously Theology After Vedanta, Seeing Through Texts, Hindu Wisdom for All
God's Children) continues the comparative theology task of 'attentive inter-textual reading. The author sets about to show the 